\title{
Carbon cycling in the northern Arabian Sea during the northeast monsoon: significance of salps
}

\author{
S. W. A. Naqvi*, V. V. S. S. Sarma, D. A. Jayakumar** \\ National Institute of Oceanography, Dona Paula, Goa 403 004, India
}

\begin{abstract}
Winter cooling and mixing brings nutrients (nitrate and phosphate) to the surface waters over large parts of the northern Arabian Sea, but the rates of primary production as well as carbon export from the euphotic zone are not especially high during the northeast monsoon. A multi-disciplinary time-series study conducted over a period of $13 \mathrm{~d}$ around $21^{\circ} \mathrm{N}, 64^{\circ} \mathrm{E}$ during the northeast monsoon of 1997 revealed substantial decreases in chlorophyll stocks in the mixed layer following the occurrence of a massive swarm of salps. A large increase in DOC was also observed during the same period. We propose that a deficiency of silicate relative to nitrate during this season may often limit the growth of diatoms, creating an ecological niche for filter feeders that can efficiently utilize abundant smaller plankton. This may lead to periodic removal of chlorophyll, thereby moderating primary production as well as episodic build-up of DOC in the upper layers. This DOC pool may be used as a nutrient source for the microbial loop in the surface layer during the following spring intermonsoon season and by the denitrifying bacteria in the oxygen-minimum zone.
\end{abstract}

KEY WORDS: Arabian Sea $\cdot$ Winter cooling $\cdot$ Carbon cycling $\cdot$ Silicate limitation $\cdot$ DOC $\cdot$ Salps

\section{INTRODUCTION}

During the northeast monsoon (NEM) season, cool and dry winds blow from the land to the ocean, causing appreciable lowering of the sea surface temperature (SST), over large parts of the northern Arabian Sea. This erodes the pycnocline and results in nutrientreplete deep ( 100 m) mixed layers (Banse 1968, 1984, 1994, Naqvi 1991, Madhupratap et al. 1996, Morrison et al. 1998). This mode of fertilization, which extends southward to at least $17^{\circ} \mathrm{N}$ latitude, is more important in the Arabian Sea than in other oceanic areas located within similar latitudinal belts for 2 reasons. First, the Arabian Sea is adjacent to a land mass in the north so that winter air temperatures are more affected (i.e. considerably lower) than those elsewhere in the tropical and subtropical Indian Ocean; and second, the suboxic layer, which is quite rich in nitrate $\left(\mathrm{NO}_{3}^{-}\right)$and

\footnotetext{
*E-mail: naqvi@csnio.ren.nic.in

${ }^{* *}$ Present address: Department of Geosciences, Princeton University, Princeton, New Jersey 08544-1003, USA
}

phosphate $\left(\mathrm{PO}_{4}{ }^{3-}\right)$, is very close (within $100 \mathrm{~m}$ ) to the sea surface so that small perturbations can bring large quantities of these nutrients into the euphotic zone. Most measurements of the NEM primary productivity (PP) made during recent Joint Global Ocean Flux Study (JGOFS) surveys in the Arabian Sea have yielded values that are higher than those suggested by historical data, but these are still lower than one would expect from the prevailing nutrient concentrations. Water column productivity has been found to be in the vicinity of $1 \mathrm{~g}$ carbon $(\mathrm{C}) \mathrm{m}^{-2} \mathrm{~d}^{-1}$ in the region of winter convection, with $\mathrm{NO}_{3}{ }^{-}$concentration exceeding $2 \mu \mathrm{M}$ (Madhupratap et al. 1996, Smith et al. 1998). This is of the same magnitude as has been measured during some oligotrophic intermonsoon periods (e.g. $727 \mathrm{mg} \mathrm{C}$ $\mathrm{m}^{-2} \mathrm{~d}^{-1}$ at $\sim 18^{\circ} \mathrm{N}, 65^{\circ} \mathrm{E}$ during April and May 1987 [Jochem et al. 1993], and $1260 \mathrm{mg} \mathrm{C} \mathrm{m}^{-2} \mathrm{~d}^{-1}$ at $\sim 16^{\circ} \mathrm{N}$, $62^{\circ} \mathrm{E}$ during November and December 1994 [Watts \& Owens 1999]). PP rates obtained during the southwest monsoon are higher, even in regions with near-zero surface $\mathrm{NO}_{3}^{-}$(e.g. $1700 \mathrm{mgC} \mathrm{m}{ }^{-2} \mathrm{~d}^{-1}$ at $13^{\circ} \mathrm{N}, 64^{\circ} \mathrm{E}$ 
during August 1996 [Kumar et al. 1999]). Rates of C export from the euphotic zone, estimated from thorium-234 ( $\left.{ }^{234} \mathrm{Th}\right)$ activity (Buesseler et al. 1998) as well as those derived from drifting sediment traps (Sarin et al. 1996) are also lower during the NEM than during the following spring intermonsoon (SI). As there is ample light and SST seldom drops below $23^{\circ} \mathrm{C}$, it would be tempting to invoke the limiting role for micronutrients such as iron (Fe). However, results of Measures \& Vink (1999) suggest that the $\mathrm{NO}_{3}^{-}$:Fe ratio is generally lower than the value $(\sim 15000$, by moles) at which Fe begins to limit phytoplankton growth. Alternatively, there may be some hitherto unrecognized biological control that might affect both PP and C export from the euphotic zone. One such control may be through grazing by zooplankton, especially large planktonic microphages such as salps.

Salps are pelagic tunicates equipped with an efficient filtering system that enables them to utilize particulate matter over a wide size range (from $<1$ to $>100 \mu \mathrm{m})$. They filter water through a continuously produced mucous net that can retain particles $>4 \mu \mathrm{m}$ with $100 \%$ efficiency; however, for smaller particles the retention efficiency decreases sharply with decreasing size to $<5 \%$ for $<1 \mu \mathrm{m}$ (Harbison \& McAlister 1979, Caron et al. 1989, Kremer \& Madin 1992). Feeding is coupled with locomotion in that the filtered

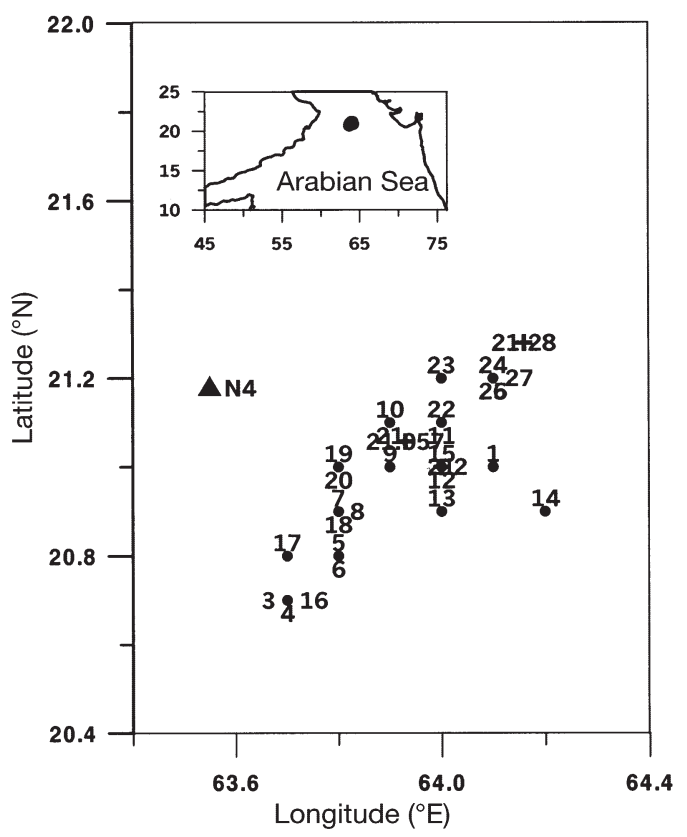

Fig. 1. Locations of sampling sites numbered serially (1-28) from $11: 40$ h on 10 February 1997 to $11: 35$ h on 23 February 1997. Circles and crosses indicate hydrocasts and primary productivity (PP) casts, respectively. The location of US Joint Global Ocean Flux Study (JGOFS) Stn N4 worked on 10 January 1995 is shown by the triangle water leaving the body of the animal produces thrust for jet-propelled swimming (Madin 1974, Alldredge \& Madin 1982). Filtration rate, which can exceed $5 \mathrm{l} \mathrm{h}^{-1}$ ind. ${ }^{-1}$ in some species, is generally unregulated, and this may cause clogging of the esophagus, sometimes fatal, when salps encounter high particle concentrations (Alldredge \& Madin 1982, Harbison et al. 1986). Under favorable conditions, however, when food is sufficient but particle density is not high enough to cause clogging, the biomass can increase explosively since salps have some of the highest growth rates among multi-cellular organisms, and, because of the exceptionally high filtration rates and the ability of the salps to retain a wide spectrum of particles, such swarms can regulate the phytoplankton biomass (Fraser 1961, Alldredge \& Madin 1982, Dubischar \& Bathmann 1997, Perissinotto \& Pakhomov 1998). Salps are also important agents for repackaging of small particles into large (>1 mm) fecal pallets. These pellets, comprising poorly digested material, are dense and have some of the highest sinking rates among biogenic particles; thus, salp swarms are believed to contribute very significantly to the vertical flux of particulate organic matter (Bruland \& Silver 1981, Alldredge \& Madin 1982, Madin 1982, Fortier et al. 1994).

Occurrence of salp swarms in the Arabian Sea is not well documented, but we have seen such swarms on several occasions in the northern region during the NEM. In this paper we argue that the nutrient distribution during the NEM creates conditions that are conducive for the development of these swarms and that they play a very significant role in $\mathrm{C}$ cycling in the region.

\section{MATERIALS AND METHODS}

A multi-disciplinary time-series study was undertaken aboard ORV 'Sagar Kanya' near latitude $21^{\circ} \mathrm{N}$, longitude $64^{\circ} \mathrm{E}$ from 10 to 23 February 1997 (Fig. 1). It included the deployment of drifting sediment traps at 140 and $300 \mathrm{~m}$ for two 4 to $5 \mathrm{~d}$ periods at the beginning and the end of the observation period, and 3 in situ PP moorings on 10, 15 and 22 February. The vessel was required to track these moorings and as a result some water-sampling stations were up to $45 \mathrm{~km}$ from the above site. On all other occasions the vessel was brought close to the nominal station position just before water sampling.

Observations in the water column were made using a conductivity-temperature-depth (CTD) recorder at $\sim 12 \mathrm{~h}$ intervals around noon and midnight Indian Standard Time. A Sea-Bird Electronics CTD-rosette sampling system (Bellevue, WA) fitted with 12 Niskin/ Go-flo samplers (1.8/12 l capacity; General Oceanics, 
Miami, FL) was used for temperature and salinity profiling and water sampling at discrete depths (indicated by dots in Fig. 2). The CTD salinities were calibrated with on-deck analysis of discrete samples using a Guildline AUTOSAL (Ocean Scientific International, Pertersfield, UK).

Chemical measurements made on board ship within a few hours of collection included dissolved oxygen and nutrients $\left(\mathrm{NO}_{3}{ }^{-}\right.$, nitrite $\left[\mathrm{NO}_{2}{ }^{-}\right]$, ammonia, $\mathrm{PO}_{4}{ }^{3-}$ and silicate $\left.\left[\mathrm{SiO}_{4}{ }^{4-}\right]\right)$. While the former was determined by the Winkler procedure, the latter were estimated colorimetrically using a Skalar Analyser (Skalar Analytical, Breda, The Netherlands) following standard techniques (Grasshoff et al. 1983). In addition, 2 profiles of DOC were taken on 12 and 19 February. Polypropylene bottles, pre-washed with $5 \%$ phosphoric acid, were used for the collection of DOC samples. Phosphoric acid $(85 \%)$ was added to the samples to bring the $\mathrm{pH}$ below 3 , after which they were stored in a refrigerator until analysis in the shore laboratory following the high-temperature catalytic oxidation method using a Shimadzu TOC 5000 analyzer (Shimadzu Corporation, Kyoto, Japan) (Sharp et al. 1993). As the analysis was carried out on unfiltered water samples, the quantity measured would be the total DOC and POC, which may, however, be assumed to comprise predominantly DOC.

PP was measured by the radiocarbon $\left({ }^{14} \mathrm{C}\right)$ method (UNESCO 1994, Bhattathiri et al. 1996). Water samples were taken from 8 depths between 0 and $150 \mathrm{~m}$ (Fig. 3) using Go-flo samplers and transferred to $300 \mathrm{ml}$ Nalgene polycarbonate bottles. After the addition of $1 \mathrm{ml}$ of aqueous solution containing $185 \mathrm{kBq}$ of ${ }^{14} \mathrm{C}\left({ }^{14} \mathrm{C}\right.$-labeled sodium carbonate/bicarbonate solution was obtained from the Board of Radioisotope Technology, Department of Atomic Energy, India), the bottles were suspended at the approximate depths of sampling using polypropylene line attached to a buoy. Three light bottles and 1 dark bottle were used at each depth. The deployment time was from $1 \mathrm{~h}$ before sunrise to $30 \mathrm{~min}$ after sunset, after which the samples were filtered through GF/F filters (nominal pore size $0.7 \mu \mathrm{m}$ ). The filters were transferred to scintillation vials containing $0.25 \mathrm{ml}$ of $0.5 \mathrm{~N}$ $\mathrm{HCl}$ and stored at room temperature until analysis in the shore laboratory. A day before the analysis, the vials were uncapped for drying at room temperature. The vials were allowed to stand for another day after the addition of liquid scintillation cocktail before they were counted in a Packard 2500 TR liquid scintillation system (Packard Instrument Co, Meriden, CT). The counted rates were converted to daily production after taking into account the initial activity in the bottles and the initial adsorption of ${ }^{14} \mathrm{C}$ by particles in the bottles. Production rates for the 3 light bottles - generally within $\pm 10 \%$ of each other-were averaged for each depth. a

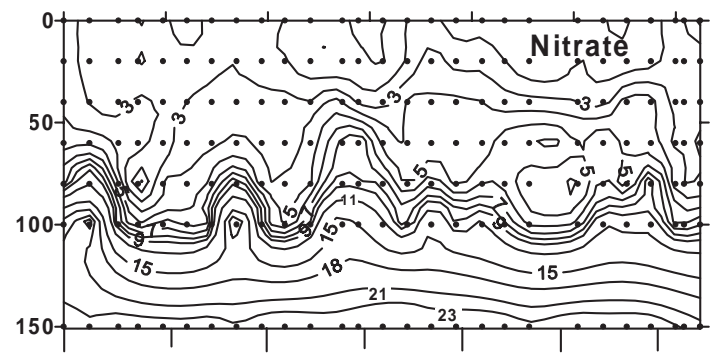

b
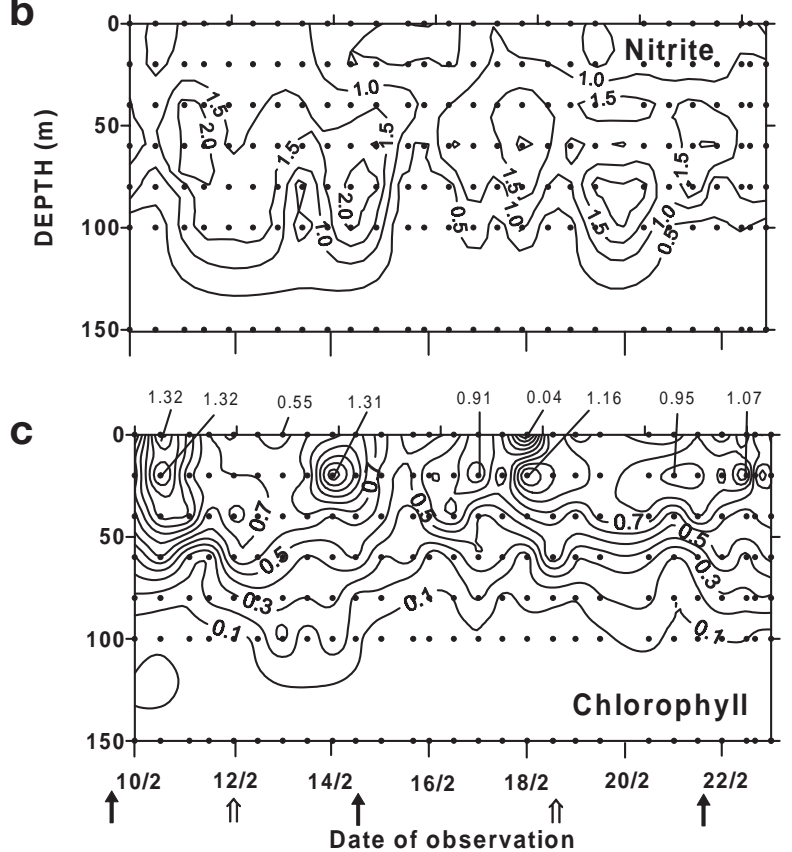

Fig. 2. Contour plots showing changes in (a) nitrate $(\mu M)$, (b) nitrite $(\mu \mathrm{M})$ and (c) chlorophyll $\left(\mathrm{mg} \mathrm{m}^{-3}\right)$ in the upper $150 \mathrm{~m}$ during 10 February 1997 to 23 February 1997 (dates marked at noon Indian Standard Time). The times of sampling for PP and DOC are indicated by solid and open arrows, respectively, on the abscissa of the lower panel

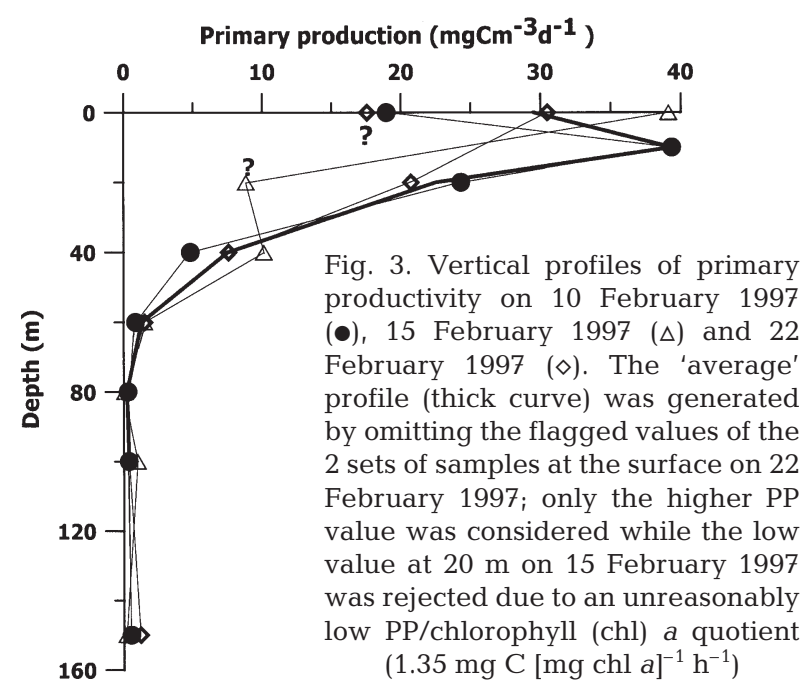


The rates for dark bottles were subtracted from those for light bottles to correct for $\mathrm{C}$ removal through non-photoautotrophic production and adsorption. Sub-samples for chlorophyll (chl) a analysis were generally taken from the same casts as nutrients. One liter of sample from each depth was filtered through GF/F filters. Following extraction with $90 \%$ acetone for $24 \mathrm{~h}$ in the dark in a refrigerator, the fluorescence was measured in a fluorometer (Turner Designs, Sunnyvale, CA) (Bhattathiri et al. 1996).

The wind speed and direction were measured at $10 \mathrm{~m}$ above the sea surface using an anemometer and a wind vane, respectively, manufactured by Dyna Laboratories (Pune). The wind data were corrected for the ship's drift.
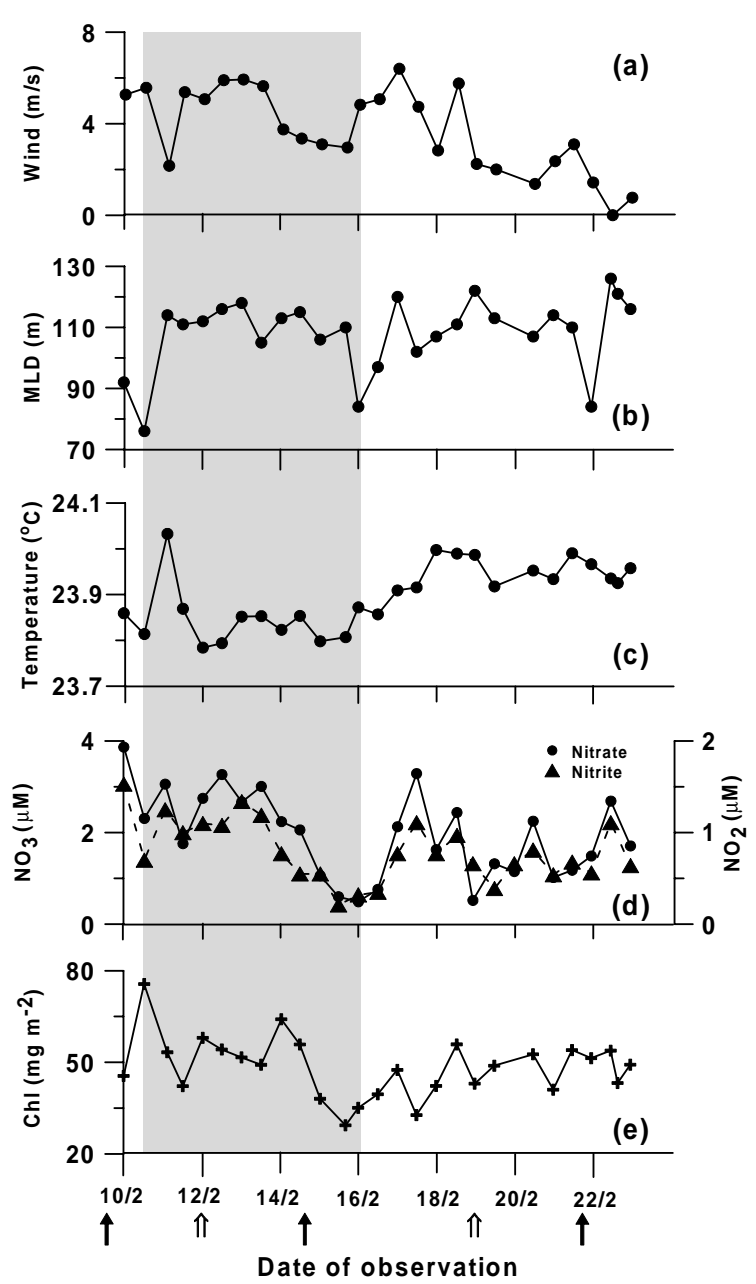

Fig. 4. Variations of (a) wind speed, (b) mixed layer depth (MLD), (c) average temperature in the upper $20 \mathrm{~m}$ (computed from the bin-averaged conductivity-temperaturedepth data at $1 \mathrm{~m}$ interval), (d) average nitrate and nitrite in the upper $20 \mathrm{~m}(\mathrm{n}=3)$ and (e) integrated chl a inventory in the upper $80 \mathrm{~m}$ with time at $\sim 21^{\circ} \mathrm{N}, 64^{\circ} \mathrm{E}$ during 10 February 1997 to 23 February 1997 (dates marked at noon Indian standard Time). Period of salp swarms indicated by the shaded region
Details of sampling and analytical protocols and data listing are given in the JGOFS (India) compact disc available on request from the Indian National Oceanographic Data Centre, NIO, Goa.

\section{RESULTS AND DISCUSSION}

Our study was conducted toward the end of the NEM, and so we had hoped to observe large changes in physical forcing and biogeochemical response. Although we did see a gradual transition from the eutrophic conditions of the NEM toward the oligotrophic ones of the SI, the magnitude of these changes was surprisingly small. For example, water temperature in the upper $20 \mathrm{~m}$ generally varied within a narrow range of $<0.25^{\circ} \mathrm{C}$ (Fig. 4c). It averaged $23.83^{\circ} \mathrm{C}$ during the first week of observations and $23.95^{\circ} \mathrm{C}$ over the next $6 \mathrm{~d}$. The mixed layer depth (MLD), defined as the level at which water temperature fell by $0.5^{\circ} \mathrm{C}$ from the surface value, was generally around $100 \mathrm{~m}$ (Fig. 4b), in agreement with previous reports (Banse 1968, 1984). Occasional oscillations in the MLD seemed to be unrelated to either the local wind speed, which generally decreased with time (Fig. 4a), or the SST (Fig. 4c). This indicates that the mixed layer temperature was controlled by large-scale processes rather than by the local weather or mixed layer dynamics.

The combined inorganic nitrogen $(\mathrm{N})$ concentrations were, in general, substantially higher than those reported previously from the zone of winter mixing (Madhupratap et al. 1996, Morrison et al. 1998). $\mathrm{NO}_{3}{ }^{-}$ accounted for the bulk of fixed $\mathrm{N}$, but $\mathrm{NO}_{2}{ }^{-}$was also present at fairly high concentrations throughout the mixed layer (Figs 2a,b \& 4d). Ammonium $\left(\mathrm{NH}_{4}^{+}\right)$was generally below the detection limit $(\sim 0.2 \mu \mathrm{M})$ of our analytical system. Highest mixed-layer $\mathrm{NO}_{3}{ }^{-}$and $\mathrm{NO}_{2}{ }^{-}$ concentrations occurred during the first few days of observations after which a general decrease was observed. This trend was often punctuated by brief enhancements of $\mathrm{NO}_{3}{ }^{-}$and $\mathrm{NO}_{2}{ }^{-}$concentrations that could not be correlated with changes in water temperature or MLD (Fig. 4).

One interesting aspect of our data is the occurrence of high $\mathrm{NO}_{2}{ }^{-}$concentrations in the mixed layer, which showed excellent correlation with $\mathrm{NO}_{3}{ }^{-}$(Fig. 5: $\mathrm{r}=$ 0.799, $\mathrm{p}<0.0001, \mathrm{n}=121$ ). Moderately high $\mathrm{NO}_{2}{ }^{-} \mathrm{accu}-$ mulation in surface waters affected by winter mixing had also been noticed on an earlier Indian JGOFS cruise (SK 99) in February and March 1995 (de Sousa et al. 1996) as well as on a US JGOFS cruise (TN 43) in January and February 1995 (Morrison et al. 1998, McCarthy et al. 1999); however, the causative mechanism has not been established. Two processes are known to result in a build-up of $\mathrm{NO}_{2}^{-}$in oxygenated 
near-surface waters: assimilatory reduction of $\mathrm{NO}_{3}^{-}$ during uptake by phytoplankton (Vaccaro \& Ryther 1960, Wada \& Hattori 1971), and differential photoinhibition of $\mathrm{NH}_{4}^{+}$and $\mathrm{NO}_{2}^{-}$oxidation by nitrifying bacteria (Olson 1981). Normally both these processes combine to produce the 'primary' $\mathrm{NO}_{2}^{-}$maximum found at the base of the euphotic zone. However, $\mathrm{NO}_{2}^{-}$ concentrations at the primary maximum are usually much lower than the mixed-layer concentrations we observed; furthermore, $\mathrm{NO}_{3}{ }^{-}$and $\mathrm{NO}_{2}{ }^{-}$concentrations at the primary maximum are not known to co-vary. As stated above, $\mathrm{NH}_{4}{ }^{+}$concentrations were below the detection limit $(0.2 \mu \mathrm{M})$ in our study. In contrast, concentrations in excess of this value were often measured on the TN 43 cruise of US JGOFS (McCarthy et al. 1999). This difference may be because our observations were made later in the NEM season. Given the low ambient $\mathrm{NH}_{4}{ }^{+}$concentrations and the known inhibition of nitrification by light (Horrigan et al. 1981, Olson 1981), it is highly unlikely that the large $\mathrm{NO}_{2}{ }^{-}$ accumulation we observed in the surface layer would have been due to nitrification. Instead, the correlation between $\mathrm{NO}_{3}{ }^{-}$and $\mathrm{NO}_{2}^{-}$strongly points to the assimilatory reduction as the dominant causative mechanism. Surface $\mathrm{NO}_{3}{ }^{-}$concentrations we encountered were slightly below those experimentally found to saturate uptake during the NEM (McCarthy et al. 1999), and so an increase in $\mathrm{NO}_{3}{ }^{-}$concentration would be expected to stimulate its uptake by phytoplankton. What is remarkable is that, given the excellent correlation between $\mathrm{NO}_{3}{ }^{-}$and $\mathrm{NO}_{2}{ }^{-}$, the rate of 'excess' $\mathrm{NO}_{2}{ }^{-}$ expulsion by the phytoplankton seems to keep pace with that of $\mathrm{NO}_{3}{ }^{-}$uptake.

However, if the accumulation of $\mathrm{NO}_{2}{ }^{-}$in the surface layer is due to assimilatory reduction by phytoplankton, one should expect a correlation between the $\mathrm{NO}_{2}{ }^{-}$ and chlorophyll concentrations. We argue later that grazing by salps may exert an important control over the chlorophyll concentration, and this may explain a lack of its covariance with $\mathrm{NO}_{2}^{-}$.

The 3 PP experiments on 10, 15 and 22 February (Fig. 3) yielded rather similar estimates of water column productivity: 975, 810 and $1080 \mathrm{mgC} \mathrm{m}^{-2} \mathrm{~d}^{-1}$, respectively. These are higher than the estimates of production made during the NEM of 1999 at the same site (643 $\mathrm{mg} \mathrm{C} \mathrm{m}^{-2} \mathrm{~d}^{-1}$ [Madhupratap et al. 1996]). Ignoring the 2 values flagged in Fig. 3, we determined an 'average' PP profile for our period of observations corresponding to a water column productivity of $1060 \mathrm{mg} \mathrm{C} \mathrm{m}^{-2} \mathrm{~d}^{-1}$. However, in order to put these data in the right perspective, the following points should be noted:

(1) As can be seen (Figs 2c \& 4e), chl a concentrations in the mixed layer showed large variations. Fortuitously, the PP measurements on all the 3 occasions

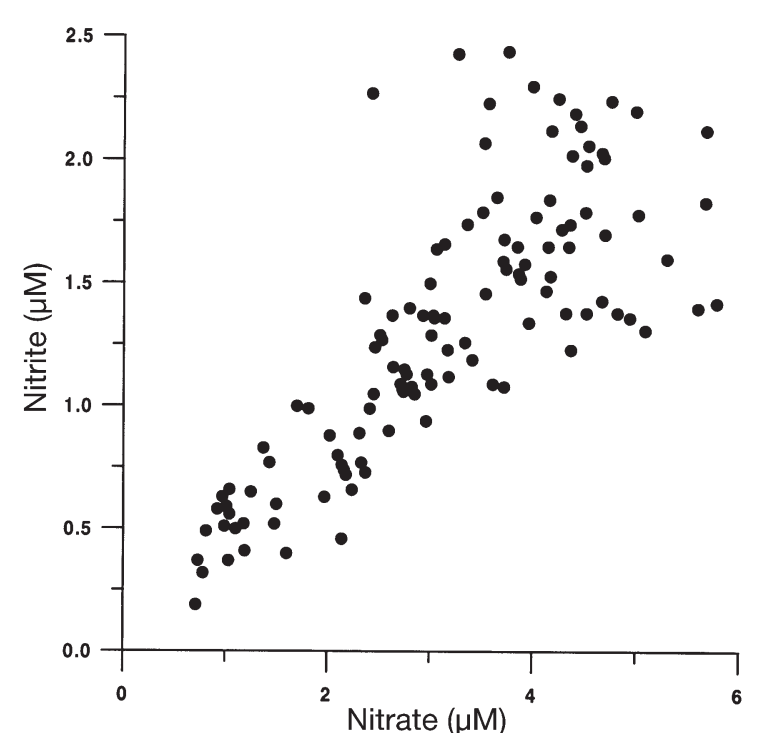

Fig. 5. A plot of nitrate versus nitrite in the surface mixed layer (above the level of a significant decrease in $\mathrm{O}_{2}$ concentration) during the entire observational period

were made when the chl stocks were relatively low: this could have led to an underestimation of average PP for the entire sampling period.

(2) The PP estimates are lower than would be expected from the observed changes in combined inorganic $\mathrm{N}$ inventory in the upper layer. This inventory was computed to a fixed depth $(80 \mathrm{~m})$ in order to exclude the effect of changes in the MLD such that it reflected mainly the average combined $\mathrm{N}$ concentration in the mixed layer. An overall decreasing trend in the inventory was discernible at an estimated rate of around $4 \mathrm{mmol} \mathrm{m}^{-2} \mathrm{~d}^{-1}$. If we assume that this decrease was caused by biological uptake, and completely ignore fresh injections of $\mathrm{NO}_{3}{ }^{-}$into the mixed layer, new production can be conservatively estimated as 312 $\mathrm{mg} \mathrm{C} \mathrm{m}{ }^{-2} \mathrm{~d}^{-1}$ from the Redfield ratio $(\mathrm{C}: \mathrm{N}=106: 16$, by atoms). This is about a third of the estimated total production. The underlying assumption that we sampled the same water mass is probably not completely valid, even for the periods of drift studies. During 11 to 15 February, for example, even though the temperaturesalinity plots for the upper water column were not too different (Fig. 6), it is possible that there was a change in water mass composition since the integrated $\mathrm{N}$ inventory decreased at an unreasonably rapid rate of $14.6 \mathrm{mmol} \mathrm{m} \mathrm{m}^{-2} \mathrm{~d}^{-1}$, corresponding to a new production rate of $1164 \mathrm{mg} \mathrm{C} \mathrm{m}^{-2} \mathrm{~d}^{-1}$. It is very hard to reconcile this rate with the measured PP rates, especially since we have ignored fresh inputs of new $\mathrm{N}$ to the system. Another possibility is that a significant fraction of PP was by picoplankton, which could have passed through the GF/F filters. However, since observations 


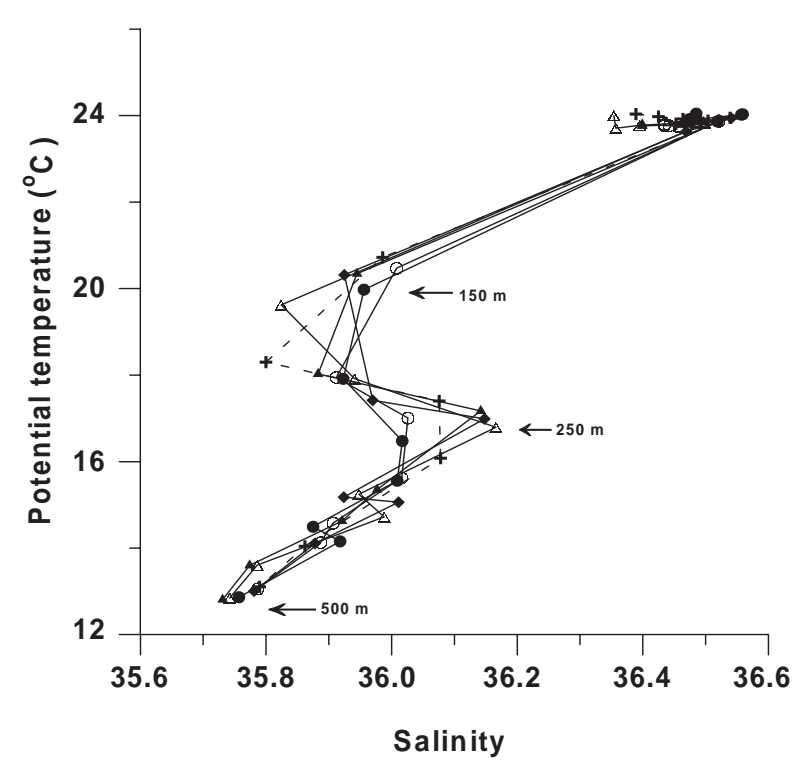

Fig. 6. Temperature versus salinity plots in the upper $500 \mathrm{~m}$ at noon on 11 February 1997 (•), 12 February 1997 (০), 13 February $1997(\diamond), 14$ February $1997(\Delta), 15$ February $1997(\Delta)$ and 19 February $1997(\boldsymbol{+})$. Approximate depths of 3 selected horizons are marked by arrows

on phytoplankton composition were not made during the cruise, their contribution to PP could not be evaluated. Alternatively, the low PP values could have arisen due to trace metal poisoning during incubation, but we discount this possibility for 2 reasons. First, using similar methods and materials (e.g. radiocarbonlabeled bicarbonate solution), we have measured PP rates up to $6 \mathrm{~g} \mathrm{C} \mathrm{m}^{-2} \mathrm{~d}^{-1}$ on other occasions (Jayakumar et al. 2001). Second, the PP:chl a quotient (averaging $2.9 \mathrm{mg} \mathrm{C}[\mathrm{mg} \mathrm{chl} \mathrm{a}]^{-1} \mathrm{~h}^{-1}$ for the 2 uppermost sampling depths at each station) is not too different from the previously reported values derived from photosynthesislight irradiance experiments conducted during the NEM in this region (2.09 to $3.31 \mathrm{mg} \mathrm{C}[\mathrm{mg} \mathrm{chl} \mathrm{a}]^{-1} \mathrm{~h}^{-1}$ by Goes et al. [1992] and $5.43 \pm 2.03 \mathrm{mg} \mathrm{C} \mathrm{[mg} \mathrm{chl} \mathrm{a]^{-1 }}$ $\mathrm{h}^{-1}$ by Sathyendranath et al. [1999]). While these observations also fortify the argument against Fe limitation of PP, they do not fully exclude the potential loss of labeled $\mathrm{C}$ through organisms smaller than the pore size of the filters used because a similar loss would occur for chl as well.

(3) The sinking fluxes of POC measured by the drifting sediment traps were very low even in relation to the measured moderate PP values: the average flux at $140 \mathrm{~m}$ was only $14 \mathrm{mg} \mathrm{C} \mathrm{m}^{-2} \mathrm{~d}^{-1}$ during 11 to 15 February and $4.5 \mathrm{mg} \mathrm{C} \mathrm{m}^{-2} \mathrm{~d}^{-1}$ during 17 to 22 February. These results are not only in conflict with the nutrient inventory data, they are also inconsistent with the published information on phytoplankton growth and mortality, which suggests a high net growth rate $\left(0.48 \mathrm{~d}^{-1}\right)$ during the NEM (Caron \& Dennet 1999). The average ratio between the rates of phytoplankton mortality to growth $\left(\mathrm{m} / \mu_{\mathrm{o}}\right)$ during the NEM (0.39 [Caron \& Dennet 1999]) was about half of the corresponding value during the southwest monsoon (0.70 [Landry et al. 1998]), which also implies that a greater fraction of primary production should be exported during the NEM (Caron \& Dennett 1999). Nevertheless, the measured low fluxes are consistent with the ${ }^{234} \mathrm{Th}$ data of Buesseler et al. (1998).

On the basis of deck incubation experiments involving ${ }^{15} \mathrm{~N}$-labeled tracers, McCarthy et al. (1999) observed a low $f$-ratio $(0.15 \pm 0.07)$ on TN 43 of US JGOFS, and attributed this to a combination of phytoplankton's preference for $\mathrm{NH}_{4}{ }^{+}$over $\mathrm{NO}_{3}{ }^{-}$and the suppressive effect of $\mathrm{NH}_{4}{ }^{+}$on $\mathrm{NO}_{3}{ }^{-}$uptake, even though the latter was found to be less in the Arabian Sea than in other oceanic regions. They concluded that while PP increased by a factor of 2 in response to nutrient enrichment brought about by winter mixing, regenerated production kept pace with total production due to an active recycling of nitrogenous nutrients. Consequently, much of the $\mathrm{NO}_{3}{ }^{-}$added to the euphotic zone was conserved for utilization during the following SI season. However, as the concentration of $\mathrm{NH}_{4}{ }^{+}$during our study was below the detection limit, its suppression of $\mathrm{NO}_{3}{ }^{-}$uptake would not have been very important. Moreover, both the observed high $\mathrm{NO}_{2}{ }^{-}$concentrations and large changes in combined $\mathrm{N}$ inventory in the mixed layer reflect an active $\mathrm{NO}_{3}{ }^{-}$uptake. The retention of most of the new production within the mixed layer as evident from the low export fluxes must therefore be due to some fundamentally different food web

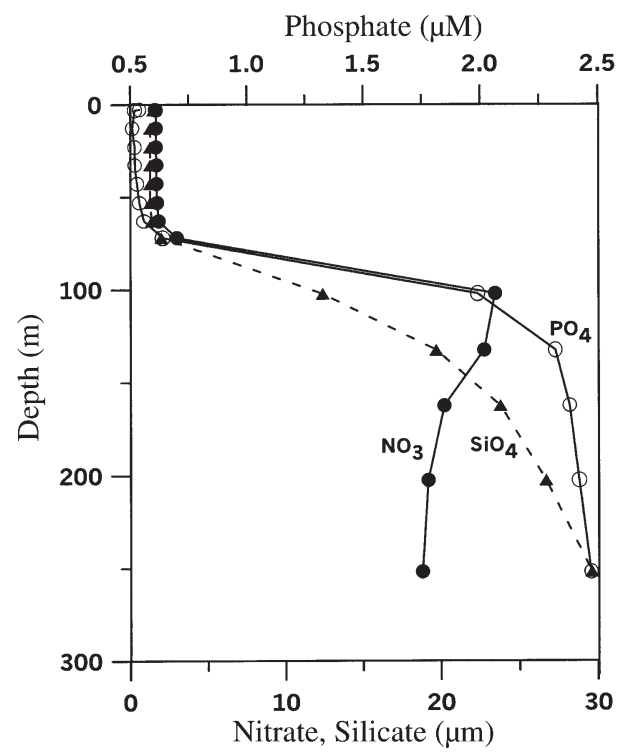

Fig. 7. Vertical profiles of nitrate, phosphate and silicate at the US JGOFS Stn N4 during Cruise TN 43 (courtesy L. A. Codispoti) 
during the NEM compared with other seasons. We suggest that this may arise from a rather peculiar nutrient distribution in the region.

Oxygen concentrations in the Arabian Sea decrease very steeply below the mixed layer accompanied by an equally sharp increase in those nutrients $\left(\mathrm{NO}_{3}{ }^{-}\right.$and $\mathrm{PO}_{4}{ }^{3-}$ ) that form the organic tissues of plankton. Thus, the $\mathrm{NO}_{3}{ }^{-}$concentration rises by $\sim 20 \mu \mathrm{M}$ within $\sim 25 \mathrm{~m}$ of the base of the mixed layer: the corresponding increase in $\mathrm{SiO}_{4}{ }^{4-}$ is more gradual (Fig. 7, based on observations at US JGOFS Stn N4 [TN 43], which were used in preference to our own data that were less precise for $\mathrm{SiO}_{4}{ }^{4-}$; see also Haake et al. 1993). Since convective mixing in the northern Arabian Sea during winter is only strong enough to erode the upper portion of the thermocline (to a depth of $120 \mathrm{~m}$ at maximum), and given the nutrient concentrations at this depth, it can bring up much more $\mathrm{NO}_{3}{ }^{-}$and $\mathrm{PO}_{4}{ }^{3-}$ than $\mathrm{SiO}_{4}{ }^{4-}$ to the mixed layer. Consequently, surface waters become $\mathrm{NO}_{3}{ }^{-}$and $\mathrm{PO}_{4}{ }^{3-}$ replete but remain $\mathrm{SiO}_{4}{ }^{4-}$ depleted. Such a situation persisted throughout our study period. Because of a technical problem with the $\mathrm{SiO}_{4}{ }^{4-}$ module of the autoanalyzer, we could not measure $\mathrm{SiO}_{4}{ }^{4-}$ during 21 to 23 February; over the remaining $10 \mathrm{~d}$ the $\mathrm{SiO}_{4}{ }^{4-}$ concentration was always indistinguishable from that of wash-water (aged surface seawater collected from the oligotrophic southern Arabian Sea). Morrison et al. (1998) have pointed out that in warm surface waters of the Arabian Sea, a net removal of $\mathrm{SiO}_{4}{ }^{4-}$ may not be possible below a concentration of $\sim 1 \mu \mathrm{M}$. The $\mathrm{SiO}_{4}{ }^{4-}$ concentration in surface waters did not exceed this value, and would in all probability limit diatom productivity.

Studies of phytoplankton composition during the NEM revealed substantial station-to-station variability, but generally a dominance of picoplanktonic and small nanoplanktonic phytoplankton has been reported (Caron \& Dennett 1999, Dennett et al. 1999). The absence of diatom blooms during this period may be principally responsible for the low POC export flux, as high export pulses are usually associated with the dominance of diatoms in the euphotic zone (Buesseler et al. 1998, Honjo et al. 1999). However, in view of the high experimentally determined net growth rates of phytoplankton and the time-invariant $\mathrm{PP}$, there must be some mechanism of removal of $\mathrm{C}$ produced in the surface layer. During our study period we witnessed such a removal by a massive swarm of salps, which appeared abruptly on 11 February. Significantly, the integrated chl a inventory within the mixed layer was at its maximum at this time (Fig. 4e). Hence, it is quite likely that a high phytoplankton biomass, which was not adequately grazed upon due to its small size-range, triggered the proliferation of these organisms. The appearance of these suspension feeders led to large biogeochemical changes, the most conspicuous of which was a sharp decline in chl a concentration: its inventory within the mixed layer had fallen by more than half by the time salps began to disappear on 16 February. The disappearance of salps coincided with the appearance of other unidentified large gelatinous organisms, and this might have contributed to additional removal of chl even after the salps were gone. The noon-time biomass of zooplankton (collected with a net of $200 \mu \mathrm{m}$ mesh size) between the surface and $120 \mathrm{~m}$ also decreased from $4.87 \mathrm{~g} \mathrm{C} \mathrm{m}^{-2}$ on 12 February to 1.93 $\mathrm{g} \mathrm{C} \mathrm{m}^{-2}$ on 18 February (data not shown). A few specimens of salps collected with a bucket and kept on deck produced numerous fecal pellets in a few hours' time, confirming their previously discussed potential for enhancing export fluxes. However, the expected large increase in the vertical POC flux was not seen in sediment traps: the maximal flux ( $32 \mathrm{mg} \mathrm{C} \mathrm{m}^{-2} \mathrm{~d}^{-1}$ at $140 \mathrm{~m}$ ) recorded on 12 February was negligible considering the amount of $\mathrm{C}$ removed. Since the fecal pellets produced by salps are robust, undergo little decay during vertical transport and have extremely high sinking rates (Caron et al. 1989), the low export flux measured by the traps is difficult to explain. Nonetheless, significant decreases (up to $\sim 70 \%$ ) in POC of the salp fecal pellets over a few hundred meters have been observed elsewhere (Matsueda et al. 1986), indicating substantial losses through horizontal advection, midwater coprophagy or interception by other particles (Caron et al. 1989). We speculate that a significant part of the pellets could have been removed in the upper layer possibly through ingestion by large zooplankton. Feeding association of salps with some specific copepods has been observed in other areas (Alldredge \& Madin 1982, Perissinotto \& Pakhomov 1997), but a lack of suitable data prevents us from investigating this aspect.

While the fate of the $\mathrm{C}$ processed by salps is not exactly known, there is some suggestion that a part of

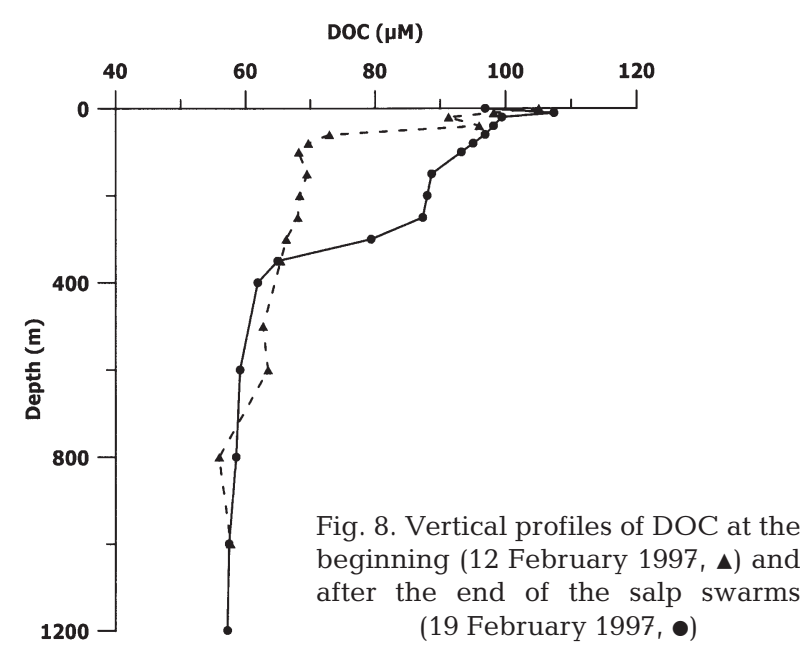


it could have been converted to DOC. The 2 profiles taken at the beginning (12 February) and after the end (19 February) of the salp swarms showed significant enrichment in DOC during the second sampling down to a depth of $\sim 350 \mathrm{~m}$ (Fig. 8), but the increase in DOC inventory was several-fold higher than the amount added by the primary production. This indicates that in addition to a probable release by the vertically migrating salps or their decaying remains that settled through the water column, there should have been additional causes of the DOC change especially below the thermocline. An examination of temperature-salinity plots (Fig. 6) reveals significant changes between the 2 sets of observations in the thermohaline structure below the thermocline to the depth where the DOC increase was observed. The most important feature of the salinity profiles in this region is the salinity maximum at $\sim 250 \mathrm{~m}$ corresponding to the Persian Gulf water; this maximum was more pronounced on 19 February than on 12 February. Significantly, Hansell \& Peltzer (1998) reported elevated DOC concentrations associated with Persian Gulf water and so a change in the proportion of this water mass also might have contributed to the observed DOC change. It may be pointed out that such a fine-scale spatial or temporal change is not uncommon in the Arabian Sea and has also been observed at drift stations previously ( $\mathrm{K}$. Banse et al. unpubl. data).

Enhanced DOC concentrations in the upper layer were also observed on cruise TN 45 of US JGOFS just after the NEM (March and April 1995) by Hansell \& Peltzer (1998). The seasonal (NEM) accumulation of DOC north of $15^{\circ} \mathrm{N}$, estimated as $31-41 \times 10^{12} \mathrm{~g} \mathrm{C}$, corresponded to $6-8 \%$ of the annual primary production and the net DOC production during this period was $\sim 80 \%$ of the net community production. While our DOC values below $350 \mathrm{~m}$ are in good agreement with the results of these workers, at shallower depths our values are higher particularly for 19 February. We do not know of any observation of salp swarms during the US JGOFS surveys, but we had noticed such swarms at $17^{\circ} \mathrm{N}, 68^{\circ} \mathrm{E}$ during a cruise of FORV 'Sagar Sampada' in February 1995; they were also found at $21^{\circ} \mathrm{N}, 64^{\circ} \mathrm{E}$ during cruise SK 99 of Indian JGOFS later during the same month (S. Raghukumar pers. comm. 1997). Their occurrence during the NEM may thus be quite common. Frequent explosions in the population of these suspension feeders have several potentially important implications for biogeochemical cycling. First, in an environment where net phytoplankton growth rates are high, it may lead to efficient removal of chl, which may exert an important control on PP. Second, these animals seem to exude large amounts of DOC, which may temporally be transported to the following SI season. This DOC may serve as a nutrient source for the microbial loop (Azam et al. 1994, Madhupratap et al. 1996). Third, as the DOC increase extends well below the mixed layer, through either migration of salps or sinking of their decaying remains, it is a potential source of C that may support high subsurface denitrification rates (Naqvi \& Shailaja 1993, Naqvi et al. 1993). However, it must be restated that we do not know what happened to the large biomass of salps as it abruptly disappeared on 16 to 17 February. If the population suddenly crashed and the remains sank through the water column, it should have led to transport of substantial organic matter in the particulate form as well. Such episodic exports, which are missed by sediment traps, must be taken into account in models of $\mathrm{C}$ cycling.

\section{SUMMARY AND CONCLUSIONS}

Some of the computations presented above (e.g. new production estimated from $\mathrm{NO}_{3}{ }^{-}$inventory vs ${ }^{14} \mathrm{C}$ based PP) should be treated with caution because of the uncertainties that arise mainly from our inability to sample the same water in an area of large fine-scale spatial variability. Nonetheless, they provide some useful insights into the dynamics of a rather unusual ecosystem. Some general conclusions that can be drawn are as follows. (1) Surface waters within the zone of winter convection are $\mathrm{NO}_{3}{ }^{-}$and $\mathrm{PO}_{4}{ }^{3-}$ enriched but $\mathrm{SiO}_{4}{ }^{4-}$ depleted due to modest cooling and resultant shallow convection coupled with the differential vertical gradients in the 2 groups of nutrients. This limits diatom productivity. However, the overall PP should still be quite high given an apparently active $\mathrm{NO}_{3}{ }^{-}$ uptake as evident from the high mixed-layer $\mathrm{NO}_{2}{ }^{-}$concentration that can only be attributed to assimilatory reduction by phytoplankton. (2) The below-expectation estimates of PP during the NEM could, in part, have been due to a possible underestimation resulting from significant production by picoplankton that could have passed through the filter papers used. More important, however, frequent proliferation of suspension feeders, particularly salps, appears to exert important checks on PP through an efficient grazing on small phytoplankton. (3) The observed changes in inorganic combined $\mathrm{N}$ inventory suggest a high rate of new production, but the POC export flux measured by drifting sediment traps deployed just below the mixed layer is an order of magnitude lower. Considered with the results of some other recent studies (Buesseler et al. 1998, McCarthy et al. 1999), our study also shows that the NEM is a season of relatively low export flux of

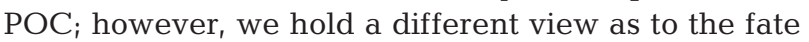
of large newly produced $\mathrm{C}$. We speculate that while a part of this is retained into the ensuing SI season as 
DOC, a significant fraction is transported downward as DOC exuded by vertically migrating salps or sinking remains of these organisms. (4) Large inputs of fresh and labile DOC to the suboxic zone may sustain high denitrification rates observed particularly during the NEM season (Naqvi et al. 1990).

Acknowledgements. We record our gratitude to the other participants of the cruise, especially Dr S. Raghukumar and Dr M. Gauns, for allowing us to use some of their data and for useful discussions. We also thank Dr E. Desa, Director, National Institute of Oceanography, for his support and encouragement. This is NIO Contribution Number 3661.

\section{LITERATURE CITED}

Alldredge AL, Madin LP (1982) Pelagic tunicates: unique herbivores in the marine plankton. Bioscience 32:655-663

Azam F, Steward GF, Smith DC, Ducklow HW (1994) Significance of bacteria in carbon fluxes in the Arabian Sea. Proc Indian Acad Sci (Earth Planet Sci) 103:243-253

Banse K (1968) Hydrography of the Arabian Sea shelf of India and Pakistan and effects on demersal fishes. Deep-Sea Res 15:45-79

Banse K (1984) Overview of the hydrography and associated biological phenomena in the Arabian Sea, off Pakistan. In: Haq BU, Milliman JD (eds) Marine geology and oceanography of the Arabian Sea and coastal Pakistan. Van Nostrand Reinhold Co, New York, p 271-303

Banse K (1994) On the coupling of hydrography, phytoplankton, zooplankton, and settling organic particles offshore in the Arabian Sea. Proc Indian Acad Sci (Earth Planet Sci) 103:27-63

Bhattathiri PMA, Pant A, Sawant S, Gauns M, Matondkar SGP, Mohanraju R (1996) Phytoplankton production and chlorophyll distribution in the eastern and central Arabian Sea in 1994-1995. Curr Sci 71:847-851

Bruland KW, Silver MW (1981) Sinking rates of fecal pellets from gelatinous zooplankton (salps, pteropods, doliolids). Mar Biol 63:295-300

Buesseler K, Ball L, Andrews J, Benitez-Nelson C, Belastock R, Chai F, Chao Y (1998) Upper ocean export of particulate organic carbon in the Arabian Sea derived from thorium234. Deep-Sea Res II 45:2461-2487

Caron DA, Dennett MR (1999) Phytoplankton growth and mortality during the 1995 northeast monsoon and spring intermonsoon in the Arabian Sea. Deep-Sea Res II 46: 1665-1690

Caron DA, Madin LP, Cole JJ (1989) Composition and degradation of salp fecal pellets: implications for vertical flux in oceanic environments. J Mar Res 47:829-850

Dennett MR, Caron DA, Murzov SA, Polikarpov IG, Gavrilova NA, Georgieva LV, Kuzmenko LV (1999) Abundance and biomass of nano- and microplankton during the 1995 northeast monsoon and spring intermonsoon in the Arabian Sea. Deep-Sea Res II 46:1691-1717

de Sousa SN, Kumar MD, Sardesai S, Sarma VVSS, Shirodkar PV (1996) Seasonal variability in oxygen and nutrients in the central and eastern Arabian Sea. Curr Sci 71: $857-862$

Dubischar CD, Bathmann UV (1997) Grazing impact of copepods and salps on phytoplankton in the Atlantic sector of the Southern Ocean. Deep-Sea Res 44:415-433
Fortier L, Le Fevre J, Legendre L (1994) Export of biogenic carbon to fish and to the deep ocean: the role of large planktonic microphages. J Plankton Res 16:809-839

Fraser JH (1961) The role of ctenophores and salps in zooplankton production and standing crop. Rapp P-V Cons Perm Int Explor Mer 153:121-123

Goes JI, Gomes HR, Kumar A, Gouveia A, Devassy VP, Parulekar AH, Rao LVG (1992) Satellite and ship studies of phytoplankton along the west coast of India. In: Desai BN (ed) Oceanography of the Indian Ocean. Oxford \& IBH Publishing Co, New Delhi, p 67-80

Grasshoff K, Ehrhardt M, Kremling K (1983) Methods of seawater analysis. Verlag Chemie, Weinheim

Haake B, Ittekkot V, Rixen T, Ramaswamy V, Nair RR, Curry WB (1993) Seasonality and interannual variability of particle fluxes to the deep Arabian Sea. Deep-Sea Res I 40: 1323-1344

Hansell DA, Peltzer ET (1998) Spatial and temporal variations of total organic carbon in the Arabian Sea. Deep-Sea Res II 45:2171-2193

Harbison GR, McAlister VL (1979) The filter-feeding rates and particle retention efficiencies of three species of Cyclosalpa (Tunicata, Thaliacea). Limnol Oceanogr 24: 875-892

Harbison GR, McAlister VL, Gilmer RW (1986) The response of the salp, Pegea confoederata, to high levels of particulate material: starvation in the midst of plenty. Limnol Oceanogr 31:371-382

Honjo S, Dymond J, Prell W, Ittekkot V (1999) Monsoon controlled export fluxes to the interior of the Arabian Sea. Deep-Sea Res II 46:1859-1902

Horrigan SC, Carlucci AF, Williams PM (1981) Light inhibition of nitrification in sea-surface film. J Mar Res 39: $557-565$

Jayakumar DA, Naqvi SWA, Narvekar PV, George MD (2001) Methane in coastal and offshore waters of the Arabian Sea. Mar Chem 74:1-13

Jochem FJ, Pollehne F, Zeitzschel B (1993) Productivity regime and phytoplankton size structure in the Arabian Sea. Deep-Sea Res II 40:711-735

Kremer P, Madin LP (1992) Particle retention efficiency of salps. J Plankton Res 14:1009-1015

Kumar SP, Madhupratap M, Muraleedharan PM, Gauns M (1999) Physical forcing and biological productivity in the Arabian Sea. International Scientific Symposium on Biogeochemistry of the Arabian Sea: Synthesis and Modelling, Programme and Abstracts. CSIR Centre for Mathematical Modeling and Computer Simulation, Bangalore, p 33

Landry MR, Brown SL, Campbell L, Constantinou J, Liu H (1998) Spatial patterns in phytoplankton growth and microzooplankton grazing in the Arabian Sea during monsoon forcing. Deep-Sea Res II 45:2353-2368

Madhupratap M, Kumar SP, Bhattathiri PMA, Kumar MD, Raghukumar S, Nair KKC, Ramaiah N (1996) Mechanism of the biological response to winter cooling in the northeastern Arabian Sea. Nature 384:549-552

Madin LP (1974) Field observations on the feeding behaviour of salps (Tunicata: Thaliaceae). Mar Biol 25:143-147

Madin LP (1982) Production, composition and sedimentation of salp fecal pellets in oceanic waters. Mar Biol 67:33-38

Matsueda H, Handa H, Inoue I, Takano H (1986) Ecological significance of salp fecal pellets collected by sediment traps in the eastern North Pacific. Mar Biol 91:421-431

McCarthy JJ, Garside C, Nevins JL (1999) Nitrogen dynamics during the Arabian Sea northeast monsoon. Deep-Sea Res II 46:1623-1664

Measures CI, Vink S (1999) Seasonal variations in the distrib- 
ution of $\mathrm{Fe}$ and $\mathrm{Al}$ in the surface waters of the Arabian Sea. Deep-Sea Res II 46:1597-1622

Morrison JM, Codispoti LA, Gaurin S, Jones B, Manghnani V, Zheng Z (1998) Seasonal variation of hydrographic and nutrient fields during the US JGOFS Arabian Sea Process Study. Deep-Sea Res II 45:2053-2101

Naqvi SWA (1991) Geographical extent of denitrification in the Arabian Sea in relation to some physical processes. Oceanol Acta 14:281-290

Naqvi SWA, Shailaja MS (1993) Activity of the respiratory electron transport system and respiration rates within the oxygen minimum layer of the Arabian Sea. Deep-Sea Res II 40:687-695

Naqvi SWA, Noronha RJ, Somasundar K, Sen Gupta R (1990) Seasonal changes in the denitrification regime of the Arabian Sea. Deep-Sea Res 37:693-711

Naqvi SWA, Kumar MD, Narvekar PV, de Sousa SN, George MD, D'Silva C (1993) An intermediate nepheloid layer associated with high microbial metabolic rates and denitrification in the Northwest Indian Ocean. J Geophys Res 98:16469-16479

Olson RJ (1981) Differential photoinhibition of marine nitrifying bacteria: a possible mechanism for the formation of the primary nitrite maximum. J Mar Res 39:227-238

Perissinotto R, Pakhomov EA (1997) Feeding association of the copepod Rhincalanus gigas with the tunicate salp Salpa thompsoni in the Southern Ocean. Mar Biol 127:479-483

Perissinotto R, Pakhomov EA (1998) Contribution of salps to

Editorial responsibility: Otto Kinne (Editor),

Oldendorf/Luhe, Germany carbon flux of marginal ice zone of the Lazarev Sea, Southern Ocean. Mar Biol 131:25-32

Sarin MM, Rengarajan R, Ramaswamy V (1996) ${ }^{234}$ Th scavenging and particle export fluxes from the upper $100 \mathrm{~m}$ of the Arabian Sea. Curr Sci 71:888-893

Sathyendranath S, Stuart V, Irwin BD, Maass H, Savidge G, Gilpin L, Platt T (1999) Seasonal variations in bio-optical properties of phytoplankton in the Arabian Sea. Deep-Sea Res II 46:633-653

Sharp JH, Suzuki Y, Munday WL (1993) A comparison of dissolved organic carbon in North Atlantic Ocean nearshore waters by high temperature combustion and wet chemical oxidation. Mar Chem 41:253-260

Smith S, Roman M, Prusova I, Wishner K and 5 others (1998) Seasonal response of zooplankton to monsoonal reversals in the Arabian Sea. Deep-Sea Res II 45:2369-2403

UNESCO (1994) Protocols for the Joint Global Ocean Flux Study (JGOFS) Core Measurement, Scientific Committee on Ocean Research. Manual and Guides 29, UNESCO Paris

Vaccaro R, Ryther JH (1960) Marine phytoplankton and the distribution of nitrite in the sea. J Cons Int Explor Mer 25: $260-271$

Wada E, Hattori A (1971) Nitrite metabolism in the euphotic layer of the central North Pacific Ocean. Limnol Oceanogr 16:766-772

Watts LJ, Owens NJP (1999) Nitrogen assimilation and the $f$ ratio in the northwestern Indian Ocean during an intermonsoon period. Deep-Sea Res II 46:725-743

Submitted: May 5, 2000 Accepted: May 8, 2001

Proofs received from author(s): January 21, 2002 